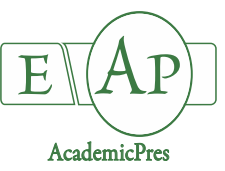

Agha MS et al. (2021)

Notulae Botanicae Horti Agrobotanici Cluj-Napoca

Volume 49, Issue 3, Article number 12461

DOI: $10.15835 /$ nbha 49312461

Research Article

\title{
Dual inoculation of Bradyrhizobium and Enterobacter alleviates the adverse effect of salinity on Glycine max seedling
}

\author{
Mona S. AGHA ${ }^{1}$, Mohamed A. ABBAS ${ }^{1}$, Mahmoud R. SOFY², \\ Samia A. HAROUN ${ }^{1}$, Amr M. MOWAFY ${ }^{1,3 *}$ \\ ${ }^{1}$ Botany Department, Faculty of Science, Mansoura University, Mansoura, 35516, \\ Egypt;mona.agha@mans.edu.eg;mabbas2010@yahoo.com; samiaharoun@mans.edu.eg; \\ ammr79@mans.edu.eg (*correspondingauthor) \\ ${ }^{2}$ Botany and Microbiology Department, Faculty of Science, Al-Azhar University, 11884 Nasr City, Cairo, \\ Egypt; Mahmoud_sofy@azhar.edu.eg \\ ${ }^{3}$ Department of Biological Sciences, Faculty of Science, New Mansoura University, New Mansoura City, \\ Egypt;ammr79@mans.edu.eg
}

\begin{abstract}
The aid of beneficial microbes, which is a well-accepted strategy, may improve plant salt tolerance. However, the mechanisms that underpin it are unclear. In this study, seedling experiments were carried out to assess the effect of Bradyrhizobium and Enterobacter on the germination, growth, nonenzymatic and enzymatic content in soybean (Glycine max L.) under salt stress. Water was sprayed on the seeds as a control, and with $75 \mathrm{mM}, 150 \mathrm{mM} \mathrm{NaCl}$ as salt stress. The findings demonstrate that salt stress $(75,150 \mathrm{mM})$ caused a significant decrease in germination, morphological criteria, and membrane stability index (MSI) when compared to control seeds but increased lipid peroxidation (MDA), electrolyte leakage (EL), osmotic pressure, proline, citric acid, sugar content, antioxidant enzymes. Furthermore, endophytic Bradyrhizobium and Enterobacter inoculation resulted in a significant rise in all of the above metrics.; however, these treatments resulted in significant reductions in ROS, EL, and MDA in stressed plants. Finally, the findings showed that combining Bradyrhizobium and Enterobacter was the most efficient in reducing the harmful effects of salt on soybean plants by boosting antioxidant up-regulation and lowering membrane leakage and ROS.
\end{abstract}

Keywords: antioxidant enzymes; endophytic; osmotic pressure; soybean

\section{Introduction}

Soil salinity harms plant growth and has become one of the major limiting factors in agricultural production throughout the globe. High salinity disturbs the cellular osmotic equilibrium by decreasing the water potential within cells, such as drought and freezing stresses (Arif et al., 2020). Ion poisoning is also caused by prolonged salt stress due to increasing $\mathrm{Na}^{+}$and $\mathrm{Cl}^{-}$ions concentrations. Such adverse circumstances cause oxidative stress by producing reactive oxygen species (ROS), such as hydrogen peroxide, superoxide, singlet oxygen, and hydroxyl radicals, all of which are harmful to cell survival (Silva et al., 2020). In NaCl-polluted soil, microbe (bio-augmentation) is an ecologically viable method of soil decontamination, which does not change

Received: 04 Aug 2021. Received in revised form: 31 Aug 2021. Accepted: 02 Sep 2021. Published online: 07 Sep 2021.

From Volume 49, Issue 1, 2021, Notulae Botanicae Horti Agrobotanici Cluj-Napoca journal uses article numbers in place of the traditional method of continuous pagination through the volume. The journal will continue to appear quarterly, as before, with four annual numbers. 
soil properties. In addition, many microorganisms can remove $\mathrm{NaCl}$ from the soil through absorption and/or precipitation. However, two factors often hamper this approach: (I) microorganism tolerance to high saline levels. (II) nutrient shortage and poor growth circumstances in these saline-stressed (Sofy et al., 2020a).

The nutrient deficit may be addressed by adding and enhancing appropriate growing conditions, but the biggest challenge is finding resistant microorganisms to high $\mathrm{NaCl}$ levels. Although some researchers believe that microbial domestication takes a long period (Komaresofla et al., 2019), soil organisms may be workable to avoid mutant bacteria in harsh environments.

Egypt often faces significant fresh irrigation water shortages, particularly after completing the Grand Ethiopian Renaissance Dam. As a result, it's critical to employ ecologically friendly methods to assist plants in withstanding salt-water usage in irrigation (Gebresenbet and Wondemagegnehu, 2021).

Foliar spraying of plants or treatment of crop seeds with plant growth-promoting bacteria (PGPB) seems to be a vital ingredient that should be verified to increase crop production under different abiotic stresses in such a justifiable manner by using beneficial microorganisms in agricultural operations (Ngalimat et al., 2021). In addition, PGPB may assist plants in coping with salt water (Kumar et al., 2020). The first is that it reduces osmotic stress by increasing osmolyte concentrations and phytohormone signals like indole-3-acetic acid (IAA) and gibberellic acid $\left(\mathrm{GA}_{3}\right)$ (Zhang et al., 2020). The second goal is to achieve ion homeostasis and improve nutritional absorption in order to reduce ion stress and nutrient deficiency (Assaha et al., 2017; Megahed et al., 2013). The third objective is to reduce oxidative stress by increasing photosynthetic capacity (Wang et al., 2020). Finally, PGPB may improve plant performance under abiotic and biotic stress conditions (Brilli et al., 2019; Megahed et al., 2012).

Soybean (Glycine max) is a significant agricultural commodity that is extensively used as human food and animal due to its high protein (18\%) and oil (38\%) content (Yasmin et al., 2020). However, it is also known for its partial salt sensitivity, which causes a $20-40 \%$ decrease in yield as salinity stress increases (Chung et al., 2020). In addition, growth, seed quantity, quality, and nodulation are all harmed by high salt stress (Adhikari et al., 2020).

This research aims to investigate the effects of Bradyrhizobium and Enterobacter inoculation on the growth, antioxidant system, and osmolytes accumulation in Glycine max seedlings under salt stress.

\section{Materials and Methods}

The isolated endophytic bacterium, Bradyrhizobium japonicum (B. japonicum; accession number EMCC No.1112), was obtained from an Egyptian agent for the American Type Culture Collection "Mircen", Ain Shams University, Cairo, Egypt. In addition, the isolated endophytic bacterium, Bacillus amyloliquefaciens (Accession number MG214652; named as MAP3), Brevibacillus parabrevis (Accession number MG214653; named as MAP4), Rhizobium leguminosarum (Accession number MG214656; named as MAPך), and Pseudomonas hibiscicola (Accession number MG21465; named as MAP8) were isolated from Vicia bean nodules. In addition, Enterobacter cloacae (Accession number MT012829; named as DeltaPSK) and Bacillus paraflexus (Accession number MT012831; named as DeltaYSK) were isolated from Lotus glaber nodules, and Pseudomonas aeruginosa (Accession number MH580294; named as ASA235) was isolated from sea sediment. These isolates were used in this study were obtained from a previous study conducted in the Botany Department, Faculty of Science, Mansoura University.

Salt tolerance capacity: the isolates' salt tolerance was assessed by observing their capacity to grow on NA media supplemented with various amounts of $\mathrm{NaCl}: 0 \mathrm{mM}, 150 \mathrm{mM}, 430 \mathrm{mM}, 860 \mathrm{mM}, 1290 \mathrm{mM}, 1720$ $\mathrm{mM}$, and $2000 \mathrm{mM}$. The cultures were incubated at $37 \pm 2{ }^{\circ} \mathrm{C}$ for 2 days in a rotating shaker incubator at 150 $\mathrm{rpm}$. Following incubation, the growth of bacteria was measured by spectrophotometry at $600 \mathrm{n} . \mathrm{m}$ (Hmaeid et al., 2019). 
Plant growth-promoting criteria: The endophytic bacteria were evaluated in vitro for plant growth promotion with and without salt $\mathrm{NaCl}$, like with indole 3-acetic acid (IAA) synthesis (Gordon and Weber, 1951), gibberellic acid $\left(\mathrm{GA}_{3}\right)$ production (Holbrook et al., 1961), ammonia production (Cappuccino and Natalie, 2005).

Siderophores production was assessed by inoculating MM9 broth medium $(15 \mathrm{ml})$ with the bacterial isolates. At $28^{\circ} \mathrm{C}$ for two days. The content of siderophores was estimated using the formula below (Schwyn and Neilands, 1987):

Ar $=$ Absorbance at $630 \mathrm{~nm}$ (CAS reagent)

Siderophores units $(\%)=\frac{A r-A s}{A r} \times 100$

As $=$ Absorbance of the sample at $630 \mathrm{~nm}$.

All endophytic bacterial applications can grow at various $\mathrm{NaCl}$ concentrations (1-11.62\%).

Preparation of bacterial inoculum:

By comparing the bacterial inoculum concentration to a $0.5 \mathrm{Mc}$-Farland turbidity standard $(1.5 \times 108$ $\mathrm{CFU} / \mathrm{mL}$ ), the bacterial inoculum concentration was adjusted (Sandrasagaran et al., 2014). Both bacterial inoculum production and seed bacterization were performed in accordance with Rajendra et al. (2006), with an inoculum concentration equal to an application rate of $10^{6} \mathrm{CFU} \mathrm{mL} \mathrm{mL}^{-1} .100 \mathrm{~mL}$ of culture suspension was added to previously sterilized prepared broth medium for each endophytic bacterial strain and incubated overnight at $30^{\circ} \mathrm{C}$ in a shaker incubator (100 rpm).

\section{Experimental design}

Soybean homogeneous seeds (Glycine max var. 'Giza11') were gained from the Agricultural Research Center, Giza, Egypt, and the experiments were conducted in the Botany Department, Faculty of Science, Mansoura University.

The seeds were surface-sterilized for 2-3 minutes with $4 \% \mathrm{NaOCl}$; after carefully rinsing with sterile water, the embryo was hydro-primed for 8 hours to activate it. The broth containing a $10 \%$ sugar solution was used to inoculate the seeds. The seeds were thoroughly agitated until a fine coating developed on them. Under laboratory settings, inoculated seeds were put overnight for drying. At $25 \pm 2{ }^{\circ} \mathrm{C}$, seeds were then germinated in Petri dishes with three layers of filter paper Whatman 1. Germination tests were carried out following the International Seed Testing Association's rules (Matthews et al., 2012). A NaCl solution of 0,75, and $150 \mathrm{mM}$ was sprayed on the seeds, and samples were collected from seedlings 10 days old. During the study, the ambient temperature, $\mathrm{CO}_{2}$, and relative humidity levels were $18-22{ }^{\circ} \mathrm{C}, 300-410 \mu \mathrm{mol} \mathrm{mol}^{-1}$, and $53-57$ percent, respectively. In a completely randomized design (CRD), fifteen treatments with 10 repetitions were used:

The treatments were designed as follows upon the salt tolerance and plant growth-promoting criteria coming in results of the tested isolates:

The first group: seeds sprayed with tap water besides these treatments

$\mathrm{T} 1$ : control with tap water only

T2: B. Japonicum

T3: B. Japonicum + MAP3

T4: B. Japonicum + MAP8

T5: B. Japonicum + Delta PSK

The second group: seeds sprayed with $75 \mathrm{mM} \mathrm{NaCl}$

T6: $(75 \mathrm{mM} \mathrm{NaCl})$

T7: B. Japonicum

T8: B. Japonicum + MAP3

T9: B. Japonicum + MAP8

T10: B. Japonicum + Delta PSK

The third group: seeds sprayed with $150 \mathrm{mM} \mathrm{NaCl}$ 
T11: $(150 \mathrm{mM} \mathrm{NaCl})$

T12: B. Japonicum

T13: B. Japonicum + MAP3

T14: B. Japonicum + MAP8

T15: B. Japonicum + Delta PSK

\section{Estimation of germination parameters}

Seedling length, seedling biomass (fresh and dry weight), and Germination percent (GP) were determined. Also, some indices were calculated as follows;

The mean germination time (MGT) was computed using (Matthews et al., 2012).

$$
\text { MGT }=\frac{\sum \mathrm{F} \times \mathrm{X}}{\sum \mathrm{F}}
$$

F: the number of newly germinated seeds at the time of $\mathrm{X}$

$\mathrm{X}$ : the number of days elapsed since sowing.

Evaluations of Pick Value (PV), Mean Daily Germination (MDG), and germination Value (GV) Germination rate were calculated by the following equations (Reyhaneh et al., 2013).

$$
\begin{gathered}
\mathrm{PV}=\frac{\text { Maximum germinated seed number at one day }}{\text { Day number }} \\
\text { MDG }=\frac{\text { Germination } \%}{\text { Total experiment days }} \\
\mathrm{GV}=\mathrm{PV} \times \mathrm{MDG}
\end{gathered}
$$

Germination rate (GR) was determined according to (Vashisth and Nagarajan, 2010):

Germination rate $(G R)=(a / 1)+(b-a / 2)+(c-b / 3)+\ldots . .+(n-n-1 / N)$

Where $\mathrm{a}, \mathrm{b}, \mathrm{c}, \ldots, \mathrm{n}$ are numbers of germinated seeds after $1,2,3, \ldots, \mathrm{N}$ days from the start of imbibition.

The seedling vigor's were calculated using (Maguire, 1962):

Vigor index I $=$ Germination $\% \times$ Seedling length $(\mathrm{cm})$

Vigor index II $=$ Germination $\% \times$ Seedling weight $(\mathrm{g})$

\section{Estimation of membrane features}

The membrane features determined here in fresh soybean seedlings contain electrolyte leakage (EL), membrane stability index (MSI), and lipid peroxidation (MDA).

Szalai et al. (1996) used to measure the seedling's electrolyte leakage (EL). First, the EC of shoot discs was measured after placing them in tubes containing $10 \mathrm{~mL}$ of boiling distilled water (EC1). Next, the EC was determined after heating the tubes in a water bath for 30 minutes at $45-55^{\circ} \mathrm{C}(\mathrm{EC} 2)$. The sample was then boiled for 10 minutes at $100^{\circ} \mathrm{C}$ to measure the EC (EC3).

The following formula was used to calculate EL:

$$
\text { Electrolyte leakage }(\%)=\frac{\mathrm{EC} 2-\mathrm{EC} 1}{\mathrm{EC} 3} \times 100
$$

Sairam (1994) calculated the membrane stability index (MSI) utilizing $200 \mathrm{mg}$ of shoot tissue in a test tube containing $10 \mathrm{~mL}$ distilled water in two sets. The first set was heated on boiling water for 30 minutes at $40^{\circ} \mathrm{C}$, and the conductivity bridge measured the solution's electrical conductivity $(\mathrm{C} 1)$. The second batch was heated for 10 minutes in $100^{\circ} \mathrm{C}$ boiling water, and its conductivity was also defined (C2).

The following formula was used to calculate the MSI:

MSI \% $=\{1-(\mathrm{C} 1 / \mathrm{C} 2)\} \times 100$

Hernández and Almansa (2002) defined malondialdehyde (MDA) to assess and quantify lipid peroxidation products. First, one gram of the shoot was soaked in $5 \mathrm{ml}$ of 0.1 percent trichloroacetic acid (TCA) and centrifuged for 5 minutes at 10,000 rpm. Then, $4 \mathrm{ml}$ of 20 percentage TCA including 0.5 percentage thiobarbituric acid was put to each $\mathrm{ml}$ of supernatant, then incubated for 30 minutes at $95^{\circ} \mathrm{C}$, 
centrifuged again, and the absorbance was measured at 532 and $600 \mathrm{~nm}$. Using an extinction coefficient of $155 \times 10-3 \mathrm{M}^{-1} \mathrm{~cm}^{-1}$.

The concentration of MDA is expressed in $\mathrm{mol} \mathrm{g}^{-1} \mathrm{~F}$ wt

Determination of oxidative damage marker

A known weight of plant shoot was homogenized in $1 \%(\mathrm{w} / \mathrm{v})$ trichloroacetic acid (TCA) and centrifuged for 15 minutes at 12,000 rpm to measure hydrogen peroxide $\left(\mathrm{H}_{2} \mathrm{O}_{2}\right) .0 .5 \mathrm{~mL}$ of the supernatant was combined with $0.5 \mathrm{~mL}$ of $100 \mathrm{mM} \mathrm{K}$ phosphate buffer $(\mathrm{pH} 7.0)$ and $2 \mathrm{~mL}$ reagent $(1 \mathrm{M} \mathrm{KI} \mathrm{w} / \mathrm{v}$ in distilled water $\mathrm{H}_{2} \mathrm{O}$ ). In the absence of seedling extract, the blank probe comprised of $1 \% \mathrm{TCA}$. The reaction was let to develop in the dark for 1 hour, and the absorbance was assessed at $390 \mathrm{~nm}$. With a molar extinction value of $0.28 \mathrm{~mol} \mathrm{~cm}^{-1}$, the amount of hydrogen peroxide was estimated (Alexieva et al., 2001).

To directly express osmotic pressure, the Electrical conductivity (EC) of plant-water extracts was assessed. For proline determination, $1 \mathrm{~mL}$ of extract, ninhydrin reagent, and glacial acetic acid were reacted in a hot water bath for an hour, and $1 \mathrm{~mL}$ of the acid was added, accompanied by chilling, increasing to $5 \mathrm{~mL}$ with the acid, then reading at $510 \mathrm{~nm}$ (Bates et al., 1973). For citric acid determination, $15 \mathrm{Ml}$ of a de-proteinizing solution ( $3 \mathrm{~g}$ of each of $\mathrm{ZnSO}_{4}$ with $\mathrm{HgCl}_{2}$ in $100 \mathrm{ml}$ of water) was incorporated into $5 \mathrm{~mL}$ of the extract and remaining overnight before filtering. Thus, $4 \mathrm{~mL}$ of $10 \mathrm{~N} \mathrm{HCl}$ with one $\mathrm{mL}$ of 6.2 percent $\mathrm{FeCl}_{3}$ were combined, and the absorbance at $445 \mathrm{~nm}$ was measured (Kolthoff and Sandell, 1948). Total soluble sugars were calculated by reacting $3 \mathrm{ml}$ of anthrone reagent and $0.1 \mathrm{ml}$ of seedling extract for 10 minutes, then measured the samples were at $625 \mathrm{~nm}$ (Irigoyen et al., 1992).

\section{Estimation of antioxidant enzymes activity}

Antioxidant enzyme activity was measured in extracts produced by chilling $2 \mathrm{~g}$ of fresh tissue with $20 \mathrm{ml}$ of $0.1 \mathrm{M}$ phosphate buffer and centrifuge cooling for 20 minutes at 10,000 rpm. In addition, catalase, peroxidase, and superoxide dismutase were extracted using a pH 6.8 buffer (Agarwal and Shaheen, 2007).

Catalase (CAT) activity was measured in $3 \mathrm{~mL}$ of a reaction mixture comprising potassium phosphate buffer, $\mathrm{pH} 7.0,11 \mathrm{mM} \mathrm{H}_{2} \mathrm{O}_{2}$, at $25^{\circ} \mathrm{C}$. UV spectrophotometry at $240 \mathrm{~nm}$ was used to assess activity by monitoring the time required for a drop-in from 0.45 to 0.40 (Mishra et al., 1993). Peroxidase (POX.) assay: 3 $\mathrm{mL}$ of $0.05 \mathrm{M}$ pyrogallol were combined with $0.1 \mathrm{~mL}$ of extract and $0.5 \mathrm{~mL}$ of $1 \% \mathrm{H}_{2} \mathrm{O}_{2}$, and the rise in absorbance at $420 \mathrm{~nm}$ was measured (ADAMS, 1978). Polyphenol oxidase (PPO), The rise in absorbance at $420 \mathrm{~nm}$ was measured after mixing two $\mathrm{ml}$ of $0.02 \mathrm{M}$ phosphate buffer at $\mathrm{pH} 7$, one $\mathrm{ml}$ of $0.05 \mathrm{M}$ pyrogallol, and one ml of the extract (Oktay et al., 1995).

\section{Statistical analysis}

The study used a completely randomized design (CRD) with fifteen treatments and ten replicates. Thus statistical analysis was done using the COSTAT software (798 Lighthouse Ave. PMB 329, Monterey, CA, 93940, USA) (Gomez and Gomez, 1984). The two-way ANOVA using Fisher's at a 95\% confidence level. XLSTAT Version 2016 was used to conduct Principal Component Analysis (PCA). Unfortunately, graph prism (version 9.1.1) drowned the graphs.

\section{Results}

\section{Salt tolerance capacity}

The salinity tolerance of the eight isolates was determined by evaluating their potential to grow in the presence of different concentrations of $\mathrm{NaCl}$. As illustrated in Figure 1, results showed a strong negative relation between salt concentrations of media $\&$ bacterial growth. First, there was a gradual decrease in the bacterial growth, accompanied by an increase of $\mathrm{NaCl}$ concentration until the maximum concentration of 860 $\mathrm{mM}$ of salt peaked. Then, the growth decreased sharply. Showing that osmo-adaptive bacteria reached the 
maximum available tolerance against the salt concentration of the media in MAP3, MAP8, DeltaPSK, $B$. japonicum, and ASA235. MAP7 and DeltaYSK, the maximum concentration was $430 \mathrm{mM}$, while in MAP4, the maximum concentration was $150 \mathrm{mM}$ (Figure 1).

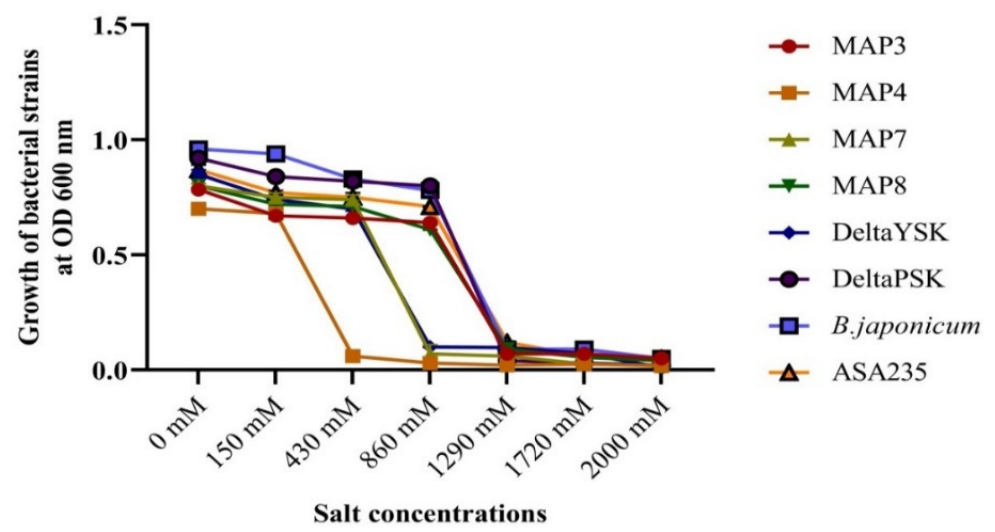

Figure 1. Effect of different salt concentrations $(0,0.87,2.5,5,7.5,10$ and $11.62 \%)$ on growth of bacterial strains at OD600 $\mathrm{nm}$ after $48 \mathrm{hrs}$

\section{Plant growth-promoting criteria of bacterial strain}

Of all 8 isolates, 4 were effective endophytic bacteria: MAP3, MAP8, Delta PSK, and B. japonicum showed the most potent result. The total amounts of IAA produced without salt were $88.3,82.1,131.5$, and $110.2 \mu \mathrm{g} \mathrm{mL}^{-1}$ and with salt were 71.3, 69.1, 94.1, and 85.4 $\mu \mathrm{g} \mathrm{mL}^{-1}$ for MAP3, MAP8, Delta PSK, and B. japonicum, respectively, with $\mathrm{GA}_{3}$ production amounts around $740.5,783.1,930.7$, and $855.4 \mu \mathrm{g} \mathrm{mL}^{-1}$ without salt, and 602.4, 608.1,701.2 and $654.1 \mu \mathrm{g} \mathrm{mL} \mathrm{m}^{-1}$ with salt.

In addition, these four isolates could produce ammonia production by $27.5,26.7,38.8$, and $18.4 \mathrm{mg} / \mathrm{ml}$ and $19,14.3,16.4$, and $18.1 \mathrm{mg} / \mathrm{ml}$ without and with salt respectively, and produced siderophores by $53.7,46.4$, 81.6, and 64.4 units and 45, 32.9, 68 and 44.8 units without and with salt respectively (Table 1).

Table 1. plant growth-promoting criteria of bacterial strains

\begin{tabular}{|c|c|c|c|c|c|c|c|c|}
\hline \multirow{2}{*}{$\begin{array}{l}\text { Bacterial } \\
\text { strains }\end{array}$} & \multicolumn{2}{|c|}{$\begin{array}{c}\text { IAA } \\
(\mu \mathrm{g} / \mathrm{ml})\end{array}$} & \multicolumn{2}{|c|}{$\begin{array}{c}\mathrm{GA}_{3} \\
(\mu \mathrm{g} / \mathrm{ml})\end{array}$} & \multicolumn{2}{|c|}{$\begin{array}{l}\text { Ammonia production } \\
(\mathrm{mg} / \mathrm{ml})\end{array}$} & \multicolumn{2}{|c|}{$\begin{array}{l}\text { Siderophores } \\
\text { (units) }\end{array}$} \\
\hline & $0 \mathrm{mM}$ & $150 \mathrm{mM}$ & $0 \mathrm{mM}$ & $150 \mathrm{mM}$ & $0 \mathrm{mM}$ & $150 \mathrm{mM}$ & $0 \mathrm{mM}$ & $150 \mathrm{mM}$ \\
\hline & $88.3 \pm 1.3 \mathrm{c}$ & $71.3 \pm 0.98 \mathrm{c}$ & $740.5 \pm 0.9 \mathrm{~d}$ & & & & $53.7 \pm 0.3^{\mathrm{d}}$ & \\
\hline MAP4 & $65.5 \pm 1.2 \mathrm{~d}$ & 404 & $722.9 \pm 0.8 \mathrm{e}$ & & & & $47.4 \pm 1.6^{\mathrm{e}}$ & $0.9^{\mathrm{e}}$ \\
\hline MAP7 & $77.8 \pm 0.5 c$ & 32.41 & $1.6 \mathrm{f}$ & 471 & $15.2 \pm$ & $9.2 \pm$ & $84.3 \pm 0.8^{b}$ & $48 \pm 1.3^{\mathrm{d}}$ \\
\hline MAP8 & $82.1 \pm 0.98 \mathrm{c}$ & $9.1 \pm$ & $783.1 \pm 1.2 \mathrm{c}$ & 608 & & $14.3=$ & $46.4 \pm 0.5^{c}$ & $32.9 \pm 1.7^{\mathrm{c}}$ \\
\hline DeltaYSK & & $9.16 \pm 1.4 \mathrm{~g}$ & & & & & $26.4 \pm 1.7^{\mathrm{f}}$ & $16.6 \pm 1.2^{f}$ \\
\hline DeltaPSK & $131.5 \pm 1.1 \mathrm{a}$ & $94.1 \pm 1.43 \mathrm{a}$ & $930.7 \pm 1.5 \mathrm{a}$ & $701.2 \pm 1.5 \mathrm{a}$ & $38.8 \pm 1^{\mathrm{a}}$ & $16.4 \pm 0.1^{\mathrm{ab}}$ & $81.6 \pm 0.9^{b}$ & $68 \pm 1.1^{\mathrm{a}}$ \\
\hline $\begin{array}{c}B . \\
\text { japonicum }\end{array}$ & $110.2 \pm 1.5 b$ & $85.4 \pm 1.6 b$ & $855.4 \pm 1.4 b$ & $654.1 \pm 1.8 \mathrm{~b}$ & $18.4 \pm 0.3^{\mathrm{ab}}$ & $18.1 \pm 0.4^{\mathrm{a}}$ & $64.4 \pm 0.6^{c}$ & $44.8 \pm 1.4^{\mathrm{de}}$ \\
\hline ASA235 & $29.1 \pm 1.8 \mathrm{e}$ & $22.6 \pm 0.8 \mathrm{f}$ & $582.6 \pm 1.5 \mathrm{~g}$ & $294.6 \pm 1.6 \mathrm{~g}$ & $13 \pm 0.96^{c}$ & $8.8 \pm 0.5^{c}$ & $95.1 \pm 0.8^{\mathrm{a}}$ & $56.1 \pm 1.70^{a}$ \\
\hline
\end{tabular}

The means $( \pm$ SE) accompanied by a different letter in each column indicate significantly different $\mathrm{p}$-value $<0.05$ by the Fisher test.

\section{Germination and morphological criteria}

Figures $(2 \mathrm{a}-\mathrm{e})$ demonstrate some of the germination parameters of soybean plants, such as germination $\%$, MGT, and plant morphology, such as seedling length and seedlings' fresh and dry weight, after being treated with $\mathrm{NaCl}$ along with different bacterial treatments with 75 or $150 \mathrm{mM} \mathrm{NaCl}$, which significantly reduced germination and morphological criteria. Germination\% and MGT reduced by $14.27 \%, 44.10 \%, 11.14 \%$, and 
$41.98 \%$, respectively, when grown under 75 and $150 \mathrm{mM} \mathrm{NaCl}$ respectively. As seeds were sprayed with 75 and $150 \mathrm{mM}$ of $\mathrm{NaCl}$, seedling length fell by approximately $25.92 \%$ and $40.95 \%$, respectively, comparing to nonsalt plants. The treatment with endophytic bacteria (B. japonicum, B. japonicum $+M A P 3, B$. japonicum + $M A P 8$, and $B$. japonicum + Delta PSK) significantly increased germination and morphological criteria in saltstressed plants compared to non-stressed plants. The most noticeable rises were observed in plants applied with B. japonicum + Delta PSK (T5), in which shoot length increased by t $34.98 \%, 51.52 \%$ for 75 , and $150 \mathrm{mM}$ for $\mathrm{NaCl}$, respectively. With an increase in $\mathrm{NaCl}$ content, the seedling's fresh and dry weight decreased. So, when soybean plants were sprayed with 75 or $150 \mathrm{mM} \mathrm{NaCl}$ solutions, the fresh and dry weight of seedlings reduced by $47.62 \%, 71.43 \%, 45.16 \%$, and $70.97 \%$, respectively, whereas treatment with $B$. japonicum + Delta PSK showed increased fresh and dry weight of seedlings by $992.73 \%, 116.67 \%, 70.59 \%$, and $200 \%$ respectively (Figure $2 \mathrm{~d}, \mathrm{e})$.
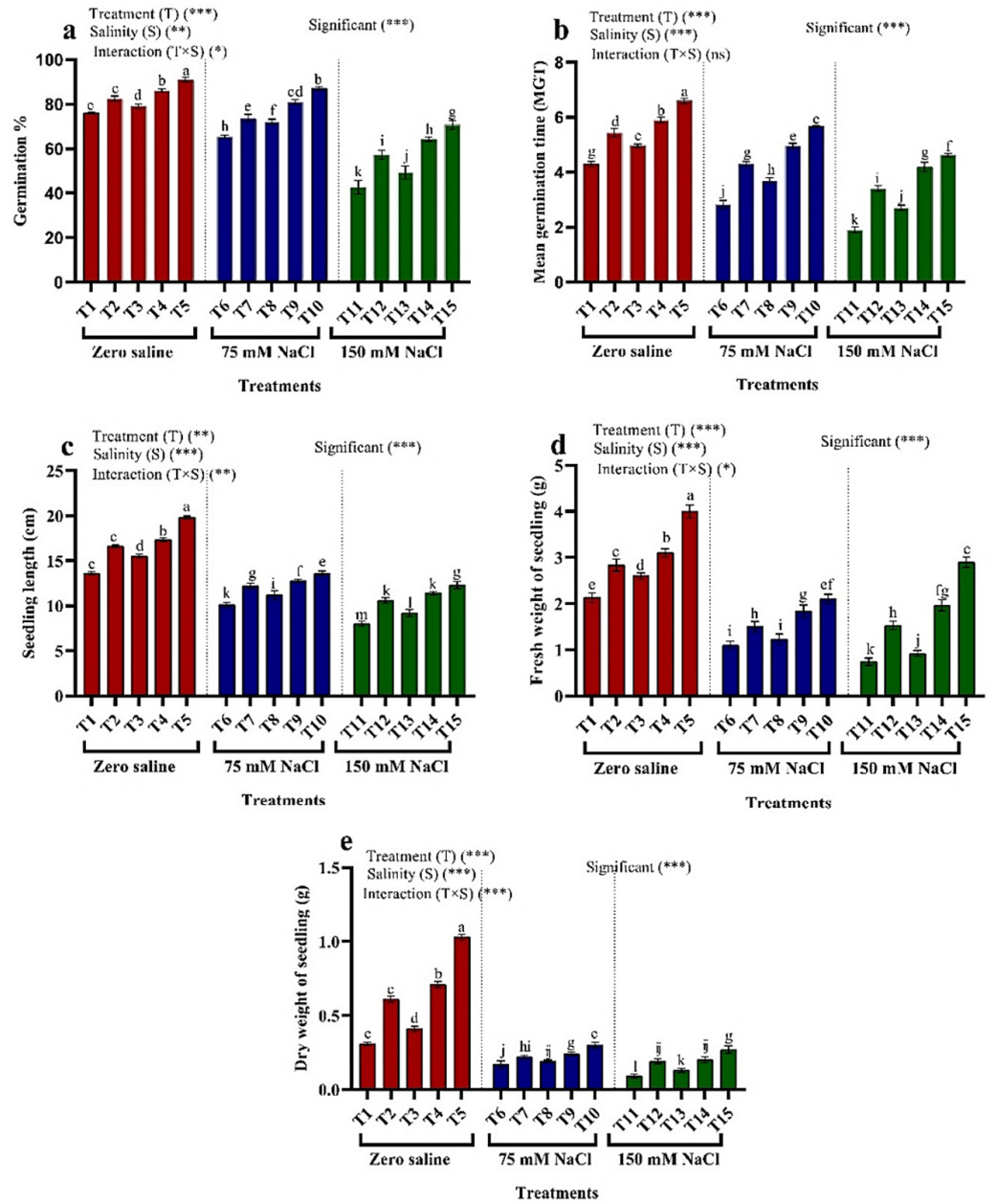

Figure 2. Effect of endophytic bacteria treated on soybean plant germination and morphological criteria under $\mathrm{NaCl}$ stress $(75,150 \mathrm{mM})$

$\mathrm{T} 1=$ control with tap water only; $\mathrm{T} 2=B$. Japonicum; $\mathrm{T} 3=B$. Japonicum + MAP3; $\mathrm{T} 4=$ B. Japonicum + MAP8; $\mathrm{T} 5=$ B. Japonicum + Delta $P S K ; \mathrm{T} 6=75 \mathrm{mM} \mathrm{NaCl} ; \mathrm{T} 7=B$. Japonicum $+75 \mathrm{mM} \mathrm{NaCl} ; \mathrm{T} 8=B$. Japonicum + MAP3 $+75 \mathrm{mM} \mathrm{NaCl} ; \mathrm{T} 9=$ B. Japonicum + MAP8 $+75 \mathrm{mM} \mathrm{NaCl} ; \mathrm{T} 10=$ B. Japonicum + Delta PSK $+75 \mathrm{mM}$ $\mathrm{NaCl} ; \mathrm{T} 11=150 \mathrm{mM} \mathrm{NaCl} ; \mathrm{T} 12=$ B. Japonicum $+150 \mathrm{mM} \mathrm{NaCl} ; \mathrm{T} 13=$ B. Japonicum + MAP3 $+150 \mathrm{mM} \mathrm{NaCl}$; $\mathrm{T} 14=$ B. Japonicum $+M A P 8+150 \mathrm{mM} \mathrm{NaCl} ; \mathrm{T} 15=$ B. Japonicum + Delta PSK+ $150 \mathrm{mM} \mathrm{NaCl}$. The Fisher test revealed different letters differ significantly from each bar $(\mathrm{p}$-value $<0.05)$. ns denotes not significant; ${ }^{*},{ }^{* *}$, and ${ }^{* * *}$ denote $(\mathrm{p}$-value $<0.01)$. 
The positive impact of endophytic bacteria; $B$. japonicum, $B$. japonicum $+M A P 3, B$. japonicum + $M A P 8$, and $B$. japonicum + Delta PSK on soybean seedling growth under saline water $(75,150 \mathrm{mM} \mathrm{NaCl})$ was determined by measuring the PV, MDG, GV, GR, Vigor index I, Vigor index II and the results are shown in Figure (3). The PV, MDG, GV, GR Vigor index I, Vigor index II of soybean seedlings exposed to salty conditions were significantly reduced. When compared to control plants, B. japonicum + Delta PSK significantly improved the seedling's PV (37.22\%), MDG (53.49\%), GV (164.89\%), GR (35.66\%), Vigor index I (79.69\%), Vigor index II (311.27\%).
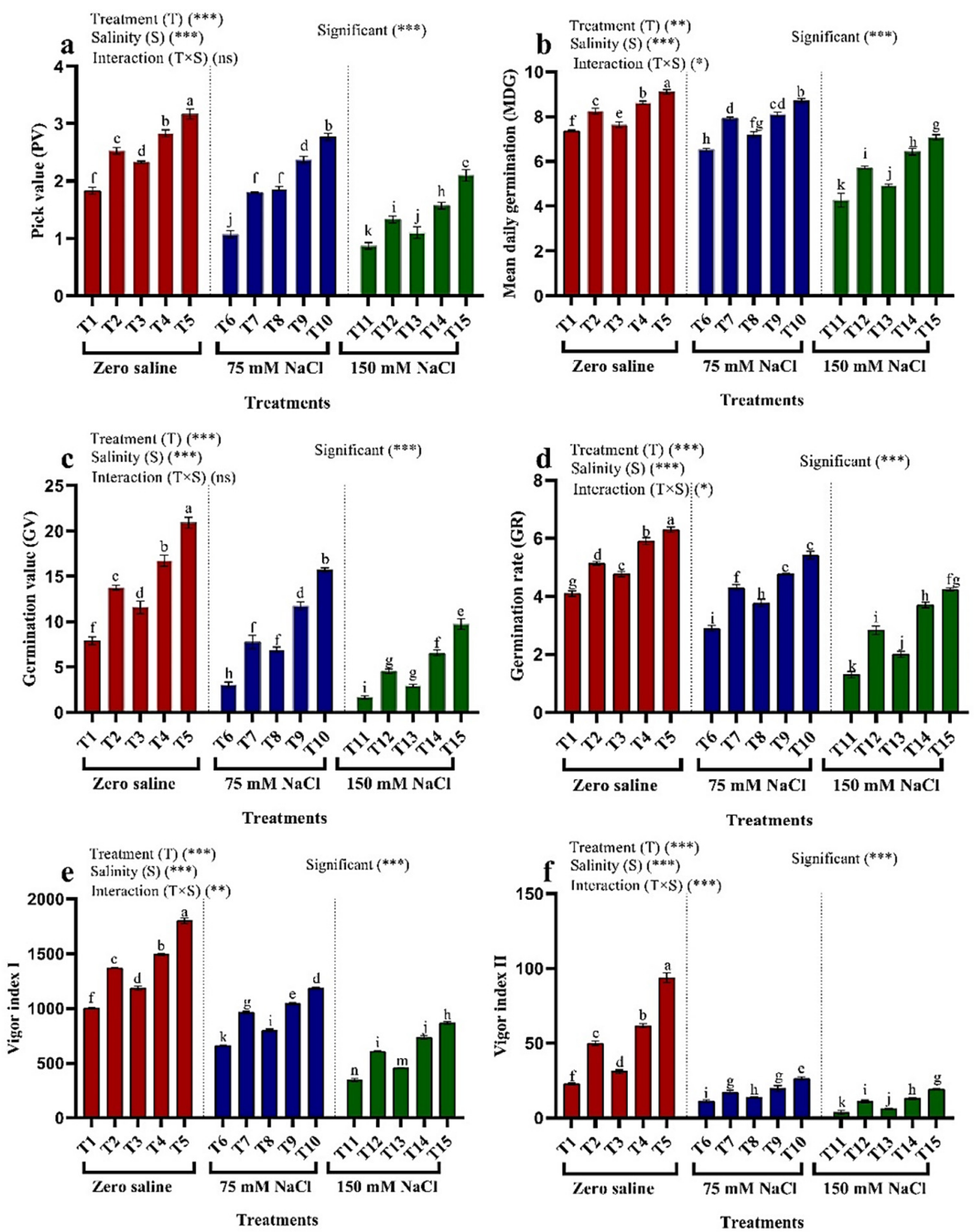

Figure 3. Effect of endophytic bacteria treated on PV, MDG, GV, GR, Vigor index I, Vigor index II of soybean plant under $\mathrm{NaCl}$ stress $(75,150 \mathrm{mM})$

$\mathrm{T} 1=$ control with tap water only; $\mathrm{T} 2=$ B. Japonicum; $\mathrm{T} 3=$ B. Japonicum + MAP3; $\mathrm{T} 4=$ B. Japonicum + MAP\&; $\mathrm{T} 5=$ B. Japonicum + Delta PSK; $\mathrm{T} 6=75 \mathrm{mM} \mathrm{NaCl} ; \mathrm{T} 7=$ B. Japonicum $+75 \mathrm{mM} \mathrm{NaCl} ; \mathrm{T} 8=$ B. Japonicum + MAP3 $+75 \mathrm{mM} \mathrm{NaCl} ; \mathrm{T} 9=$ B. Japonicum + MAP\& $+75 \mathrm{mM} \mathrm{NaCl} ; \mathrm{T} 10=$ B. Japonicum + Delta $P S K+75 \mathrm{mM}$ $\mathrm{NaCl} ; \mathrm{T} 11=150 \mathrm{mM} \mathrm{NaCl} ; \mathrm{T} 12=$ B. Japonicum $+150 \mathrm{mM} \mathrm{NaCl} ; \mathrm{T} 13=$ B. Japonicum + MAP3 $+150 \mathrm{mM} \mathrm{NaCl}$; $\mathrm{T} 14=$ B. Japonicum + MAP\&+ $150 \mathrm{mM} \mathrm{NaCl} ; \mathrm{T} 15=$ B. Japonicum + Delta $P S K+150 \mathrm{mM} \mathrm{NaCl}$. The Fisher test revealed different letters differ significantly from each bar $(\mathrm{p}$-value $<0.05)$. ns denotes not significant; ${ }^{*},{ }^{* *}$, and ${ }^{* * *}$ denote $(\mathrm{p}$-value $<0.01)$. 


\section{Estimation of membrane features}

The electrolyte leakage (EL) significantly increased in seedlings under $\mathrm{NaCl}$ stress compared with nonsaline plants but showed a significant $(\mathrm{P}<0.05)$ decrease when seedling was treated with $B$. japonicum + Delta $P S K$ under $\mathrm{NaCl}$ stress (Figure $4 \mathrm{a}$ ). However, $\mathrm{NaCl}$ stress caused a significant rise in MDA content in seedlings compared with control plants. Inoculating $B$. japonicum + Delta $P S K$ with $\mathrm{NaCl}$ significantly $(\mathrm{P}<0.05)$ decreased the MDA content. B. japonicum + Delta PSK inoculation improved MSI in soybean plants during favorable control conditions compared with saline and non-saline conditions. salinity reduced MDA (23.72\%) for $75 \mathrm{mM} \mathrm{NaCl}$ and (46.73\%) for $75 \mathrm{mM} \mathrm{NaCl}$ (Figure $4 \mathrm{~b}$ ).
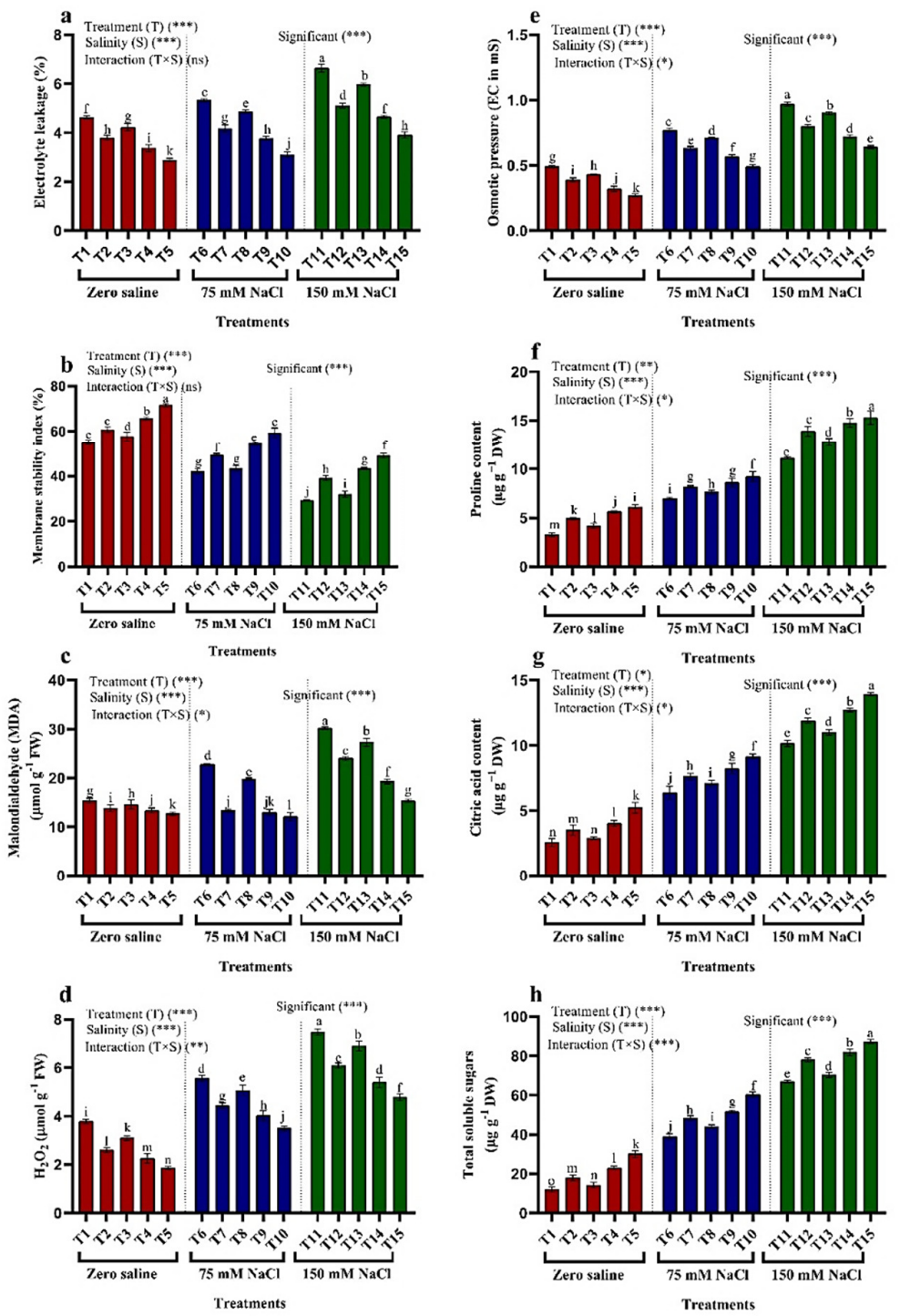

Figure 4. Effect of endophytic bacteria treated on membrane features and oxidative damage marker of soybean plant under $\mathrm{NaCl}$ stress $(75,150 \mathrm{mM})$

$\mathrm{T} 1=$ control with tap water only; $\mathrm{T} 2=B$. Japonicum; $\mathrm{T} 3=$ B. Japonicum + MAP3; $\mathrm{T} 4=$ B. Japonicum + MAP8; $\mathrm{T} 5=$ B. Japonicum + Delta PSK; T6 $=75 \mathrm{mM} \mathrm{NaCl} ; \mathrm{T} 7=$ B. Japonicum $+75 \mathrm{mM} \mathrm{NaCl} ; \mathrm{T} 8=B$. Japonicum + MAP3 + $75 \mathrm{mM} \mathrm{NaCl} ; \mathrm{T} 9=$ B. Japonicum + MAP8 $+75 \mathrm{mM} \mathrm{NaCl} ; \mathrm{T} 10=$ B. Japonicum + Delta PSK $+75 \mathrm{mM}$ $\mathrm{NaCl} ; \mathrm{T} 11=150 \mathrm{mM} \mathrm{NaCl} ; \mathrm{T} 12=$ B. Japonicum $+150 \mathrm{mM} \mathrm{NaCl} ; \mathrm{T} 13=$ B. Japonicum + MAP3 $+150 \mathrm{mM} \mathrm{NaCl} ;$ $\mathrm{T} 14=$ B. Japonicum + MAP\& $150 \mathrm{mM} \mathrm{NaCl} ; \mathrm{T} 15=$ B. Japonicum + Delta PSK+ $150 \mathrm{mM} \mathrm{NaCl}$. The Fisher test revealed different letters differ significantly from each bar $(\mathrm{p}$-value $<0.05)$. ns denotes not significant; ${ }^{*},{ }^{* *}$, and ${ }^{* * *}$ denote ( $\mathrm{p}$-value $<0.01)$. 


\section{Oxidative damage marker}

One of the harmful effects of salt stress is oxidative damage to cell membranes. To examine the role of endophytic bacteria in oxidative damage, we next measured the reactive oxygen species production in soybean seedling sprayed with $\mathrm{NaCl}(75,150 \mathrm{mM})$. Under salt stress $(75,150 \mathrm{mM})$ the $\mathrm{H}_{2} \mathrm{O}_{2}(46.97 \%, 97.36 \%$,), osmatic pressure $(57.14 \%, 97.96 \%)$, proline $(114.64 \%, 241.54 \%$,), citric acid $(148.83 \%, 296.88 \%$,) and total soluble sugar contents $(225 \%, 458.3 \%$,) were increased compared to $75,150 \mathrm{mM} \mathrm{NaCl}$, respectively (Figure 4 d-h). Meanwhile, treatment with B. japonicum + Delta PSK significantly decreased the $\mathrm{H}_{2} \mathrm{O}_{2}$ content and osmatic pressure, while treatment with B. japonicum + Delta PSK significantly increased the proline, citric acid, and total soluble sugar contents as compared to salt stress.

\section{Antioxidant enzymes activity}

Under salt stress and non-stress circumstances, the activities of antioxidant enzymes were evaluated to assess the positive impact of endophytic bacteria; B. japonicum, B. japonicum $+M A P 3$, B. japonicum + MAP8, and B. japonicum + Delta PSK (Figure 5). Furthermore, the impact of endophytic bacteria under saline or nonsaline stress increased the activities of antioxidant enzymes such as CAT, POX, and PPO in plants.
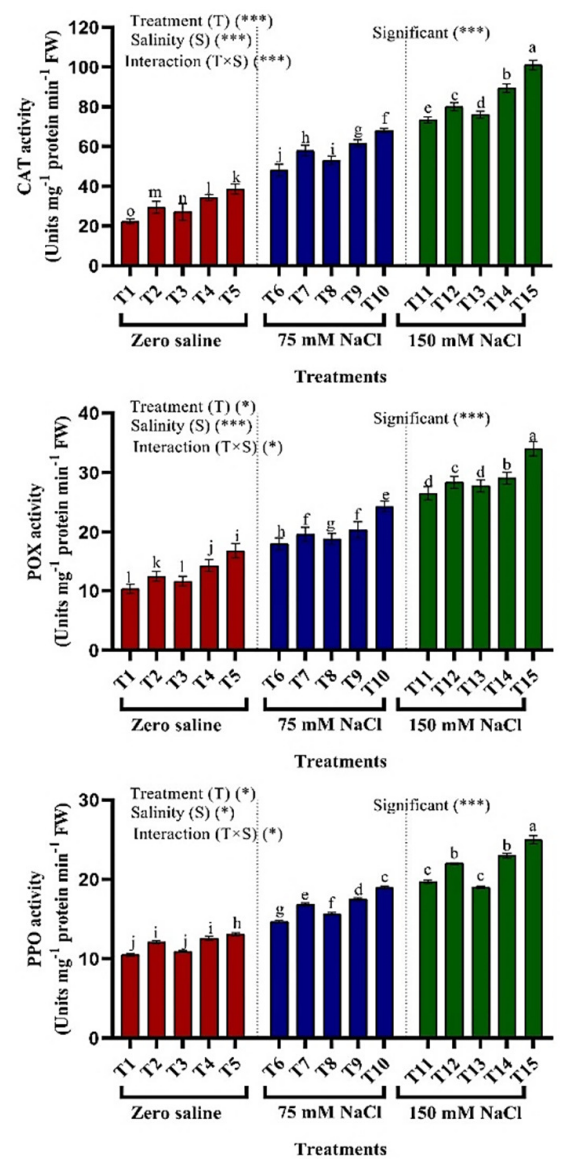

Figure 5. Effect of endophytic bacteria treated on the antioxidant enzyme of soybean plant under $\mathrm{NaCl}$ stress $(75,150 \mathrm{mM})$

$\mathrm{T} 1=$ control with tap water only; $\mathrm{T} 2=B$. Japonicum; $\mathrm{T} 3=B$. Japonicum + MAP3; $\mathrm{T} 4=$ B. Japonicum + MAP8; $\mathrm{T} 5=$ B. Japonicum + Delta PSK $; \mathrm{T} 6=75 \mathrm{mM} \mathrm{NaCl} ; \mathrm{T} 7=$ B. Japonicum $+75 \mathrm{mM} \mathrm{NaCl} ; \mathrm{T} 8=B$. Japonicum + $M A P 3+75 \mathrm{mM} \mathrm{NaCl} ; \mathrm{T} 9=$ B. Japonicum + MAP8 $+75 \mathrm{mM} \mathrm{NaCl} ; \mathrm{T} 10=$ B. Japonicum + Delta PSK $+75 \mathrm{mM}$ $\mathrm{NaCl} ; \mathrm{T} 11=150 \mathrm{mM} \mathrm{NaCl} ; \mathrm{T} 12=$ B. Japonicum $+150 \mathrm{mM} \mathrm{NaCl} ; \mathrm{T} 13=$ B. Japonicum + MAP3 $+150 \mathrm{mM} \mathrm{NaCl}$; $\mathrm{T} 14=$ B. Japonicum + MAP $8+150 \mathrm{mM} \mathrm{NaCl} ; \mathrm{T} 15=$ B. Japonicum + Delta PSK+ $150 \mathrm{mM} \mathrm{NaCl}$. The Fisher test revealed different letters differ significantly from each bar ( $\mathrm{p}$-value $<0.05){ }^{*}$, and ${ }^{* * *}$ denote $(\mathrm{p}$-value $<0.01)$ 


\section{Principal component analysis (PCA)}

To explain the multi-factorial impacts of our treatments on all variables (germination growth, enzymatic and nonenzymatic oxidants) of soybean plants under $\mathrm{NaCl}$ stress and non-saline conditions, principal component analysis (PCA) was used (Figure 6). The cross-validation technique requires the use of two major components to describe the variation of the studied features. The two factors (PC1 and PC2) were derived from the eigenvalues of the covariance matrix. They account for $90.37 \%$ of data variability $(75.61 \%$ and $14.76 \%$ for PC1 and PC2, respectively).

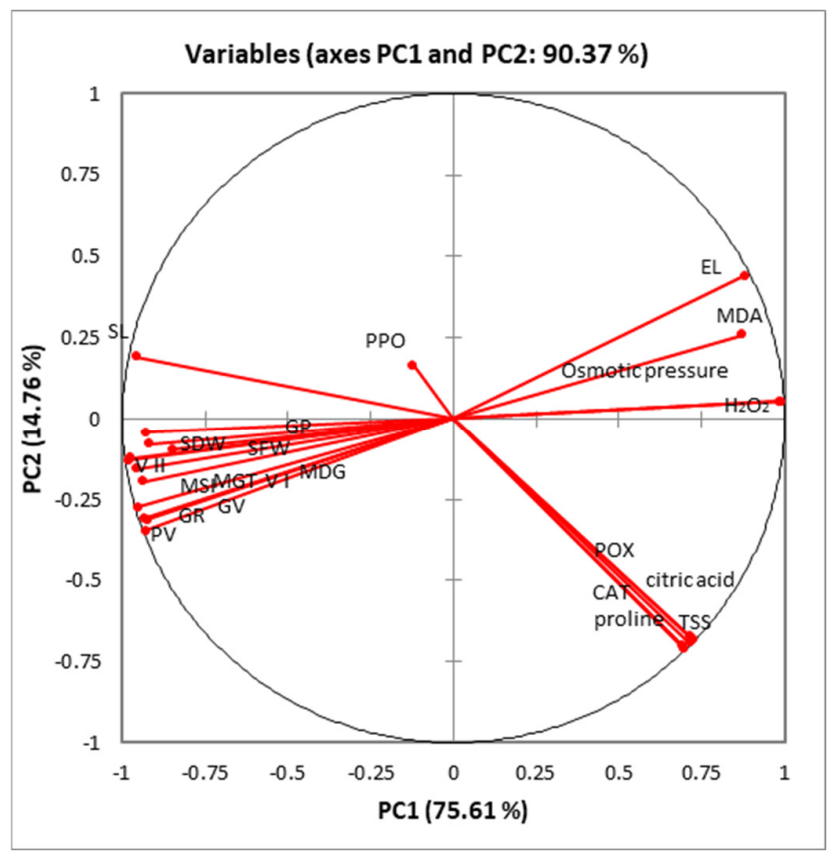

Figure 6. Principal component analysis was used to understand variable treatment relationships in soybean plants better

The variables contain SFW (fresh shoot weight), SDW (shoot dry weight), SL (shoot length), MGT (mean Germination time), PV (Pick Value), GV (Germination Value), MDG (Mean Daily Germination), GR (Germination rate), VI (Vigor index I), MDA (malondialdehyde), H2O2 (hydrogen peroxide), EL (electrolyte leakage), PPO (Polyphenol oxidase), CAT (catalase), POX (peroxidase) and TSS (total soluble sugar).

\section{Discussion}

Salt is one of the fundamental soil degradation issues and caused crop production loss (Sofy et al., 2021c). On the other hand, the preventive effect of salinity on plant improvement maybe because of the excessive osmotic potential, ion toxicity, the close of stomata, which reduces $\mathrm{CO}_{2}$ absorption and limits photosynthetic apparatus (Mbarki et al., 2018). Therefore, substituting salinity-responsible ions is deemed worthy of improving saline soils, either synthetically or by incorporating microbial communities or carbon-based substances (Ilangumaran and Smith, 2017).

Endophytic bacteria may solubilize micro and macro elements for plants and enhance macronutrient mobilization and absorption by complex solubilizing compounds in the soil and transferring them to their plant (Etesami, 2020). The utilization of microbes in $\mathrm{NaCl}$-polluted soil is an ecologically friendly way to decontaminate the soil without changing its properties. Absorption and/or precipitation by a variety of microorganisms may decontaminate $\mathrm{NaCl}$ from the soil. Using soil organisms in severe environments to avoid mutant microbes may be viable (Etesami and Alikhani, 2019). 
Under both unstressed and salt-stressed conditions, treatment with endophytic bacteria; $B$. japonicum, B. japonicum + MAP3, B. japonicum + MAP8, and B. japonicum + Delta PSK increased seedling germination and morphological criteria (germination percent, MGT, Seedling length, fresh and dry weight of seedling, PV, MDG, GV, GR, Vigor (Figures 2,3).

Previous research (Yadav et al., 2018; Alraey et al., 2019; Nawaz et al., 2020) showed many bacterial sp. from the genera Pseudomonas, Exiguobacteriumd Bacillus play an essential role in plant growth promotion under growth-limiting circumstances.

These results are in line with those of Sofy et al. (2021d), who discovered that salt stress reduced the fresh and dry shoot weight as well as the root weight of pea plants. However, bacterial treatments have a significant increase in the root, shoot lengths, fresh, dry root, and shoot weights under salinity conditions. Yasmin et al. (2020) also demonstrated that application with PGPB caused a highly significant increase in morphological criteria of soybean plants under salt stress. Valenzuela-Aragon et al. (2019) found coinoculation of wheat plants with Enterobacter cloacae, the plant growth-promoting bacteria, has increased morphological criteria.

Due to osmotic stress and ion toxicity, salinity dramatically changes plant biochemical and physiological consequences, resulting in a severe decrease in root water uptake (Sofy et al., 2020b).

MDA and electrolyte leakage are the most frequently used parameters to evaluate the degree of salt damage and determine plant salt tolerance (Mansour et al., 2020). In addition, EL and MDA showed a doseresponse relationship with $\mathrm{NaCl}$ in the current research, as $\mathrm{EL}$ and MDA increase when the $\mathrm{NaCl}$ levels increase (Figure 4). On the contrary, plants treated with B. japonicum + Delta PSK depicted a reduction in EL and MDA. Cen et al. (2020) found a comparable decrease in EL and MDA in alfalfa plants due to salt exposure. Thus, endophytic bacteria reduced the harmful effects of salt stress on maize by increasing plant tolerance to $\mathrm{NaCl}$, as shown by lower EL and MDA levels (Li et al., 2020). However, Mahmoud et al. (2020); Sofy et al. (2020c) suggested that high EL could signify high potassium content in the plant. Our findings stated that an increase in EL \% primarily owes cell membrane injury problems due to excess oxidative stress caused by $\mathrm{NaCl}$. A further source of evidence for our theory, the EL\% is the significant decrease in MSI (Figure 4 a,b), which shows a dose-response relationship to salinity as MSI reduced to its lowest recorded value at $150 \mathrm{mM} \mathrm{NaCl}$. On the other hand, higher MSI values were observed in plants that received endophytic bacteria, particularly in B. japonicum + Delta PSK, which exhibited a significant increase in MSI and membrane integrity.

Extensive reactive oxygen species (ROS) development under salinity stress is like other stressful circumstances. Considerable amounts of oxidative biomarkers like $\mathrm{H}_{2} \mathrm{O}_{2}$ were significantly increased under environmental stresses and used as a positive parameter to evaluate plants' tolerance to saline stress (Desoky et al., 2020; Sofy et al., 2021a). This study showed that all oxidative biomarkers were relatively low by inoculation of endophytic bacteria concerning the levels reported in salt-stressed plants. The current study's findings prove the observational data reported recently (Gupta and Pandey, 2020). From a physiological perspective, the increased prevalence of $\mathrm{H}_{2} \mathrm{O}_{2}$ content in soybean plants has been related to increased plasma membrane destruction and dehydration cytoplasm resulting from severe salinity stress. $\mathrm{H}_{2} \mathrm{O}_{2}$ is responsible for the increased solute degradation related to oxidative stress (Silva et al., 2020; Mohamed et al., 2012,2016). Lastochkina et al. (2020) noted the pattern of clarification close to our observation. Dual inoculation with $B$. japonicum and Delta PSK can be regarded as a promising source for preserving the integrity of the plasma membrane and regulating water intake, and increasing water use efficiency, thus minimizing oxidative stress (Harman et al., 2019). Egamberdieva et al. (2017) state that it may benefit from B. japonicum + Pseudomonas putida to increase water availability and decrease soil salinity. The potential benefit of $B$. japonicum is increased crop yield, and biomass production in bean plants under salt stress conditions decreased the quantity of $\mathrm{O}_{2}{ }^{--}$, MDA, and $\mathrm{H}_{2} \mathrm{O}_{2}$ (Meena et al., 2020; El-Beltagi et al., 2019).

Lastochkina (2019) reported that PGPB was proposed to reduce MDA to a minimum level to counteract salinity conditions. Proline reduces the detrimental effects of salinity by mediating ROS scavenging to maintain proteins and other essential biomolecular structures, in addition to the crucial function of proline, 
citric acid, and total soluble sugar levels in the maintenance of cell water balance (Abu-Shahba et al., 2021). Other studies support the proline synthesis observed on the PGPR-inoculated plants in this study. For example, Mowafy et al. (2021) found that PGPR enhanced proline aggregation, resulting in better water absorption, water quality, and photosynthetic efficiency in maize plants.

ROS molecules must be detoxified to reduce injury under stressful conditions. In addition, the efficient destruction of ROS requires the coordination of many antioxidant enzymes (Sofy et al., 2021b). Multiple scavenging enzymes, like CAT, POX, and PPO, reduce the impact of ROS. On the other hand, many antioxidant enzymes are fully dedicated to maintaining ROS homeostasis, while others are involved in growth, redox control of target proteins, and detoxification processes (El-Beltagi et al., 2018; El-Beltagi et al., 2020). Under salt stress, the activity of antioxidant enzymes including CAT, POX, and PPO significantly increased, helping to control ROS accumulation (Figure 5). High levels of antioxidant activity have been observed in plants under stress irrigated with $150 \mathrm{mM} \mathrm{NaCl}$ alone or in combination with endophytic bacteria; $B$. japonicum, B. japonicum $+M A P 3$, B. japonicum $+M A P 8$, and B. japonicum + Delta PSK compared to control plants and salt-stressed plants. Increasing enzyme activity in stressed soybean plants is an effective strategy for coping with the harmful effects of salt stress and scavenging reactive oxygen species that cause oxidative stress in plants. The role of PGPB in alleviating salt stress could be attributable to an auxiliary mechanism (Zhang et al., 2019). Antioxidant enzymes increase, implying that more and more ROS is needed, and such ROS effects are decreased. CAT plays an essential role in the elimination of $\mathrm{H}_{2} \mathrm{O}_{2}$ from the cell's various organelles. POX is also engaged in $\mathrm{H}_{2} \mathrm{O}_{2}$ scavenging and plays an essential function in stress tolerance (Sharaf et al., 2009; Mohamed et al., 2018). ROS-scavenging enzymes like CAT and PPO were significantly increased in different crops inoculated by PGP microbial isolates in saline conditions (Hmaeid et al., 2019).

\section{Conclusions}

Endophytic bacteria are recognized for being osmoregulated, its accumulation in plant tissues, on the other hand, depends on plant species and agriculture methods. This protection is closely linked to improving germination and morphological criteria, MSI, MDA osmolytes, by reducing oxidative stress caused by ROS and regulating the activity of antioxidant enzymes (CAT, POX, and PPO). In addition, the inoculation of $\mathrm{B}$. japonicum + Delta PSK in $\mathrm{NaCl}$ may increase the tolerance of plants to salt stress by reducing the oxidative damage caused by ROS production. However, the results appear that the dual inoculation of $B$. japonicum and Delta PSK is more effective than others. This result paved the way for the use of such a combination in a pot experiment to verify its potentiality to overcome salinity stress on soybean yield.

\section{Authors' Contributions}

Conceptualization: MSA, MAA, SAH and AMM; Data curation; Formal analysis; Funding acquisition; Investigation; Methodology; Project administration; Resources; Software; Supervision; Validation; Visualization: MSA, MAA, SAH and AMM; Writing - original draft; Writing - review and editing. MSA, MAA, SAH, MRS and AMM. All authors read and approved the final manuscript.

\section{Acknowledgements}

This research received no specific grant from any funding agency in the public, commercial, or not-forprofit sectors. 
Agha MS et al. (2021). Not Bot Horti Agrobo 49(3):12461

\section{Conflict of Interests}

The authors declare that there are no conflicts of interest related to this article.

\section{References}

Abu-Shahba MS, Mansour MM, Mohamed HI, Sofy MR (2021). Comparative cultivation and biochemical analysis of iceberg lettuce grown in sand soil and hydroponics with or without microbubbles and macrobubbles. Journal of Soil Science and Plant Nutrition 21(1):389-403. https://doiorg/10.1007/s42729-020-00368-X

Adams JB (1978). The inactivation and regeneration of peroxidase in relation to the high temperature-short time processing of vegetables. International Journal of Food Science \& Technology 13(4):281-297. https://doi.org/10.1111/j.1365-2621.1978.tb00806.x

Adhikari B, Dhungana SK, Kim ID, Shin DH (2020). Effect of foliar application of potassium fertilizers on soybean plants under salinity stress. Journal of the Saudi Society of Agricultural Sciences 19(4):261-269. https://doi.org/10.1016/j.jssas.2019.02.001.

Agarwal S, Shaheen R (2007). Stimulation of antioxidant system and lipid peroxidation by abiotic stresses in leaves of Momordica charantia. Brazilian Journal of Plant Physiology 19(2):149-161. https://doi.org/10.1590/s167704202007000200007

Alexieva V, Sergiev I, Mapelli S, Karanov E (2001). The effect of drought and ultraviolet radiation on growth and stress markers in pea and wheat. Plant, Cell \& Environment 24(12):1337-1344. https://doi.org/10.1046/j.13653040.2001.00778.X

Alraey DA, Haroun SA, Omar MN, Abd-ElGawad AM, El-Shobaky AM, Mowafy AM (2019). Fluctuation of essential oil constituents in Origanum syriacum subsp. sinaicum in response to plant growth promoting bacteria. Journal of Essential Oil Bearing Plants 22(4):1022-1033. https://doi.org/10.1080/0972060X.2019.1661794

Arif Y, Singh P, Siddiqui H, Bajguz A, Hayat S (2020). Salinity induced physiological and biochemical changes in plants: An omic approach towards salt stress tolerance. Plant Physiology and Biochemistry 156:64-77. https://doi.org/10.1016/j.plaphy.2020.08.042

Assaha DV, Ueda A, Saneoka H, Al-Yahyai R, Yaish MW (2017). The role of $\mathrm{Na}^{+}$and $\mathrm{K}^{+}$transporters in salt stress adaptation in glycophytes. Frontiers in Physiology 8:509. https://doi.org/10.3389/fphys.2017.00509

Bates LS, Waldren RP, Teare ID (1973). Rapid determination of free proline for water-stress studies. Plant and Soil 39(1):205-207. https://doi.org/10.1007/BF00018060

Brilli F, Pollastri S, Raio A, Baraldi R, Neri L, Bartolini P, Podda A, Loreto F, Maserti BE, Balestrini R (2019). Root colonization by Pseudomonas chlororaphis primes tomato (Lycopersicum esculentum) plants for enhanced tolerance to water stress. Journal of plant physiology 232:82-93. https://doi.org/10.1016/j.jplph.2018.10.029

Cappuccino JG, Natalie S (2005). Microbiology: A Laboratory Manual.

Cen H, Wang T, Liu H, Tian D, Zhang Y (2020). Melatonin application improves salt tolerance of alfalfa (Medicago sativa L.) by enhancing antioxidant capacity. Plants 9(2):220. https://doi.org/10.3390/plants9020220.

Chung YS, Kim K-S, Hamayun M, Kim Y (2020). Silicon confers soybean resistance to salinity stress through regulation of reactive oxygen and reactive nitrogen species. Frontiers in Plant Science 10:1725. https://doi.org/10.3389/fpls.2019.01725.

Desoky E-SM, Saad AM, El-Saadony MT, Merwad A-RM, Rady MM (2020). Plant growth-promoting rhizobacteria: Potential improvement in antioxidant defense system and suppression of oxidative stress for alleviating salinity stress in Triticum aestivum (L.) plants. Biocatalysis and Agricultural Biotechnology 30:101878. https://doi.org/10.1016/j.bcab.2020.101878.

Egamberdieva D, Wirth S, Jabborova D, Räsänen LA, Liao H (2017). Coordination between Bradyrhizobium and Pseudomonas alleviates salt stress in soybean through altering root system architecture. Journal of Plant Interactions 12(1):100-107. https://doi.org/10.1080/17429145.2017.1294212

El-Beltagi HS, Mohamed HI, Megahed BM, Gamal M, Safwat G (2018). Evaluation of some chemical constituents, antioxidant, antibacterial and anticancer activities of Beta vulgaris L. root. Fresenius Environmental Bulletin 27(9):6369-6378. 
El-Beltagi HS, Mohamed HI, Safwat G, Gamal M, Megahed B (2019). Chemical composition and biological activity of Physalis peruviana L. Gesunde Pflanzen 71:113-122.

El-Beltagi HS, Sofy MR, Aldaej MI, Mohamed HI (2020). Silicon alleviates copper toxicity in flax plants by up-regulating antioxidant defense and secondary metabolites and decreasing oxidative damage. Sustainability 12(11):4732. https://doi.org/10.3390/su12114732

Etesami H (2020). Enhanced phosphorus fertilizer use efficiency with microorganisms' nutrient dynamics for sustainable crop production. Springer, 215-245. https://doi.org/10.1007/978-981-13-8660-2_8

Etesami H, Alikhani HA (2019). Halotolerant plant growth-promoting fungi and bacteria as an alternative strategy for improving nutrient availability to salinity-stressed crop plants saline soil-based agriculture by halotolerant microorganisms. Springer, 103-146. https://doi.org/10.1007/978-981-13-8335-9_5

Gebresenbet F, Wondemagegnehu DY (2021). New dimensions in the Grand Ethiopian Renaissance dam negotiations: ontological Security in Egypt and Ethiopia. African Security 1-27. https://doi.org/10.1080/19392206.2021.1905921

Gomez KA, Gomez AA (1984). Statistical Procedures for Agricultural Research. John Wiley \& Sons Inc, Singapore.

Gordon SA, Weber RP (1951). Colorimetric estimation of indoleacetic acid. Plant Physiology 26(1):192-195. https://doi.org/10.1104/pp.26.1.192

Gupta S, Pandey S (2020). Enhanced salinity tolerance in the common bean (Phaseolus vulgaris) plants using twin ACC deaminase producing rhizobacterial inoculation. Rhizosphere 16:100241. https://doi.org/10.1016/j.rhisph.2020.100241

Harman GE, Doni F, Khadka RB, Uphoff N (2019). Endophytic strains of Trichoderma increase plants' photosynthetic capability. Journal of Applied Microbiology 130(2):529-546. https://doi.org/10.1111/jam.14368

Hernández JA, Almansa MS (2002). Short-term effects of salt stress on antioxidant systems and leaf water relations of pea leaves. Physiologia Plantarum 115(2):251-257. https://doi.org/10.1034/j.1399-3054.2002.1150211.x

Hmaeid N, Wali M, Metoui-Ben Mahmoud O, Pueyo JJ, Ghnaya T, Abdelly C (2019). Efficient rhizobacteria promote growth and alleviate $\mathrm{NaCl}$-induced stress in the plant species Sulla carnosa. Applied Soil Ecology 133:104-113. https://doi.org/10.1016/j.apsoil.2018.09.011

Holbrook AA, Edge WJW, Bailey F (1961). Spectrophotometric method for determination of gibberellic acid gibberellinS. Advances in Chemistry 28:159-167.

Ilangumaran G, Smith DL (2017). Plant growth promoting rhizobacteria in amelioration of salinity stress: a systems biology perspective. Frontiers in Plant Science 8:1768. https://doi.org/10.3389/fpls.2017.01768

Irigoyen JJ, Einerich DW, Sánchez-Díaz M (1992). Water stress induced changes in concentrations of proline and total soluble sugars in nodulated alfalfa (Medicago sativa) plants. Physiologia Plantarum 84(1):55-60. https://doi.org/10.1111/j.1399-3054.1992.tb08764.x

Kolthoff IM, Sandell EB (1948). Colorimetric methods of analysis. The Journal of Physical and Colloid Chemistry 52(7):1265-1266. https://doi.org/10.1021/j150463a020

Komaresofla BR, Alikhani HA, Etesami H, Khoshkholgh-Sima NA (2019). Improved growth and salinity tolerance of the halophyte Salicornia sp. by co-inoculation with endophytic and rhizosphere bacteria. Applied Soil Ecology 138:160-170. https://doi.org/10.1016/j.apsoil.2019.02.022.

Kumar A, Singh S, Gaurav AK, Srivastava S, Verma JP (2020). Plant growth-promoting bacteria: biological tools for the mitigation of salinity stress in plants. Frontiers in Microbiology 11:1216. https://doi.org/10.3389/fmicb.2020.01216

Lastochkina O (2019). Bacillus subtilis-mediated abiotic stress tolerance in plants. In: Islam MT, Rahman MM, Pandey P, Boehme MH, Haesaert G (Eds). Bacilli and Agrobiotechnology: Phytostimulation and Biocontrol: Volume 2. Springer International Publishing, Cham, pp 97-133. https://doi.org/10.1007/978-3-030-15175-1-6

Lastochkina O, Pusenkova L, Garshina D, Yuldashev R, Shpirnaya I, Kasnak C, ... Aliniaeifard S (2020). The effect of endophytic bacteria Bacillus subtilis and salicylic acid on some resistance and quality traits of stored Solanum tuberosum L. tubers infected with Fusarium dry rot. Plants 9(6):738. https://doi.org/10.3390/plants9060738

Li X, Sun P, Zhang Y, Jin C, Guan C (2020). A novel PGPR strain Kocuria rhizophila Y1 enhances salt stress tolerance in maize by regulating phytohormone levels, nutrient acquisition, redox potential, ion homeostasis, photosynthetic capacity and stress-responsive genes expression. Environmental and Experimental Botany 174:104023. https://doi.org/10.1016/j.envexpbot.2020.104023

Maguire JD (1962). Speed of germination-aid in selection and evaluation for seedling emergence and vigor. Crop Science 2(2). https://doi.org/10.2135/cropsci1962.0011183X000200020033x 
Agha MS et al. (2021). Not Bot Horti Agrobo 49(3):12461

Mahmoud LM, Dutt M, Shalan AM, El-Kady ME, El-Boray MS, Shabana YM, Grosser JW (2020). Silicon nanoparticles mitigate oxidative stress of in vitro-derived banana (Musa acuminata 'Grand Nain') under simulated water deficit or salinity stress. South African Journal of Botany 132:155-163. https://doi.org/10.1016/j.sajb.2020.04.027

Mansour E, Moustafa ES, Desoky E-SM, Ali M, Yasin MA, Attia A, Alsuhaibani N, Tahir MU, El-Hendawy S (2020). Multidimensional evaluation for detecting salt tolerance of bread wheat genotypes under actual saline field growing conditions. Plants 9(10):1324. https://doi.org/10.3390/plants9101324

Matthews S, Noli E, Demir I, Khajeh-Hosseini M, Wagner M-H (2012). Evaluation of seed quality: from physiology to international standardization. Seed Science Research 22(S1):69-S73. https://doi.org/10.1017/S0960258511000365

Mbarki S, Sytar O, Cerda A, Zivcak M, Rastogi A, He X, Zoghlami A, Abdelly C, Brestic M (2018). Strategies to mitigate the salt stress effects on photosynthetic apparatus and productivity of crop plants. Salinity Responses and Tolerance in Plants 1:85-136. https://doi.org/10.1007/978-3-319-75671-4-4

Meena M, Swapnil P, Divyanshu K, Kumar S, Harish, Tripathi YN, Zehra A, Marwal A, Upadhyay RS (2020). PGPRmediated induction of systemic resistance and physiochemical alterations in plants against the pathogens: Current perspectives. Journal of Basic Microbiology 60(10):828-861. https://doi.org/10.1002/jobm.202000370

Megahed A, El-Dougdoug K, Othman B, Lashin S, Ibrahim M, Sofy A (2012). A new Egyptian satellite strain of cucumber mosaic cucumovirus. International Journal of Virology 8(3):240-257. https://doi.org/10.3923/ijv.2012.240.257

Megahed A, KhA E-D, Othman B, Lashin S, Ibrahim M, Sofy A (2013). Induction of resistance in tomato plants against tomato mosaic tobamovirus using beneficial microbial isolates. Pakistan Journal of Biological Sciences16(8):385-390. https://doi.org/10.3923/pjbs.2013.385.390

Mishra NP, Mishra RK, Singhal GS (1993). Changes in the activities of anti-oxidant enzymes during exposure of intact wheat leaves to strong visible light at different temperatures in the presence of protein synthesis inhibitors. Plant Physiology 102(3):903-910. https://doi.org/10.1104/pp.102.3.903

Mohamed HI, Aly AA, Mansour MTM, El-Samawaty AMA (2012). Association of oxidative stress components with resistance to flax powdery mildew. Tropical Plant Pathology 37(6):386-392.

Mohamed HI, Elsherbiny EA, Abdelhamid MT (2016). Physiological and biochemical responses of Vicia faba Plants to foliar application of zinc and iron. Gesunde Pflanzen 68(4):201-212.

Mohamed HI, El-Beltagi HS, Aly AA, Latif HH (2018). The role of systemic and non systemic fungicides on the physiological and biochemical parameters in Gossypium hirsutum plant, implications for defense responses. Fresenius Environmental Bulletin 7(12):8585-8593.

Mowafy AM, Fawzy MM, Gebreil A, Elsayed A (2021). Endophytic Bacillus, Enterobacter, and Klebsiella enhance the growth and yield of maize. Acta Agriculturae Scandinavica, Section B - Soil \& Plant Science 71(4):237-246. https://doi.org/10.1080/09064710.2021.1880621

Nawaz A, Shahbaz M, Imran A, Marghoob MU, Imtiaz M, Mubeen F (2020). Potential of salt tolerant PGPR in growth and yield augmentation of wheat (Triticum aestivum L.) under saline conditions. Frontiers in Microbiology 11:2019. https://doi.org/10.3389/fmicb.2020.02019

Ngalimat MS, Mohd Hata E, Zulperi D, Ismail SI, Ismail MR, Mohd Zainudin NAI, Saidi NB, Yusof MT (2021). Plant growth-promoting bacteria as an emerging tool to manage bacterial rice pathogens. Microorganisms 9(4):682. https://doi.org/10.3390/microorganisms9040682

Oktay M, Küfreviolu I, Kocaçalişkan I, Şaklrolu H (1995). Polyphenoloxidase from Amasya apple. Journal of Food Science 60(3):494-496. https://doi.org/10.1111/j.1365-2621.1995.tb09810.x

Rajendra L, Samiyappan R, Raguchander TG, Saravanakumar D (2006). Endophytic bacterial induction of defence enzymes against bacterial blight of cotton. Phytopathologia Mediterranea 45(3):203-214.

Reyhaneh A, Hassan F, Mohammad KH (2013). Can bulk and nanosized titanium dioxide particles improve seed germination features of wheatgrass (Agropyron desertorum). Notulae Scientia Biologicae 5(3). https://doi.org/10.15835/nsb539072

Sairam RK (1994). Effect of moisture stress on physiological activities of two contrasting wheat genotypes. Indian Journal of Experimental Biology 3:584-593.

Sandrasagaran UM, Subramaniam S, Murugaiyah V (2014). New perspective of Dendrobium crumenatum orchid for antimicrobial activity against selected pathogenic bacteria. Pakistan Journal of Botany 46(2):719-724. 
Schwyn B, Neilands JB (1987). Universal chemical assay for the detection and determination of siderophores. Analytical Biochemistry 160(1):47-56. https://doi.org/10.1016/0003-2697(87)90612-9

Sharaf AEM, Farghal II, Sofy MR (2009). Response of broad bean and lupin plants to foliar treatment with boron and zinc. Australian Journal of Basic and Applied Sciences 3:2226-2231.

Silva PCC, Azevedo Neto ADd, Gheyi HR, Ribas RF, Silva CRdR, Cova AMW (2020). Salt tolerance induced by hydrogen peroxide priming on seed is related to improvement of ion homeostasis and antioxidative defense in sunflower plants. Journal of Plant Nutrition 44(8):1207-1221. https://doi.org/10.1080/01904167.2020.1862202

Sofy AR, Sofy MR, Hmed AA, Dawoud RA, Alnaggar AE-AM, Soliman AM, El-Dougdoug NK (2021a). Ameliorating the adverse effects of tomato mosaic tobamovirus infecting tomato plants in Egypt by boosting immunity in tomato plants using zinc oxide nanoparticles. Molecules 26(5):1337. https://doi.org/10.3390/molecules26051337

Sofy AR, Sofy MR, Hmed AA, Dawoud RA, Refaey EE, Mohamed HI, El-Dougdoug NK (2021b). Molecular characterization of the Alfalfa mosaic virus infecting Solanum melongena in Egypt and the control of its deleterious effects with melatonin and salicylic acid. Plants 10(3):459. https://doi.org/10.3390/plants10030459

Sofy M, Mohamed H, Dawood M, Abu-Elsaoud A, Soliman M (2021c). Integrated usage of arbuscular mycorrhizal and biochar to ameliorate salt stress on spinach plants. Archives of Agronomy and Soil Science 1-22. https://doi.org/10.1080/03650340.2021.1949709

Sofy MR, Aboseidah AA, Heneidak SA, Ahmed HR (2021d). ACC deaminase containing endophytic bacteria ameliorate salt stress in Pisum sativum through reduced oxidative damage and induction of antioxidative defense systems. Environmental Science and Pollution Research 1-21. https://doi.org/10.1007/s11356-021-13585-3

Sofy MR, Elhawat N, Alshaal T (2020a). Glycine betaine counters salinity stress by maintaining high $\mathrm{K}+/ \mathrm{Na}+$ ratio and antioxidant defense via limiting $\mathrm{Na}+$ uptake in common bean (Phaseolus vulgaris L.). Ecotoxicology and Environmental Safety 200:110732. https://doi.org/10.1016/j.ecoenv.2020.110732

Sofy MR, Elhindi KM, Farouk S, Alotaibi MA (2020b). Zinc and paclobutrazol mediated regulation of growth, upregulating antioxidant aptitude and plant productivity of pea plants under salinity. Plants 9(9):1197. https://doi.org/10.3390/plants9091197

Sofy AR, Dawoud RA, Sofy MR, Mohamed HI, Hmed AA, El-Dougdoug NK (2020c). Improving regulation of enzymatic and nonenzymatic antioxidants and stress-related gene stimulation in Cucumber mosaic cucumovirus infected cucumber plants treated with glycine betaine, chitosan and combination. Molecules 25:2341. https://doi.org/10.3390/molecules25102341

Szalai G, Janda T, Páldi E, Szigeti Z (1996). Role of light in the development of post-chilling symptoms in maize. Journal of Plant Physiology 148(3):378-383. https://doi.org/10.1016/S0176-1617(96)80269-0

Valenzuela-Aragon B, Parra-Cota FI, Santoyo G, Arellano-Wattenbarger GL, de los Santos-Villalobos S (2019). Plantassisted selection: a promising alternative for in vivo identification of wheat (Triticum turgidum L. subsp. Durum) growth promoting bacteria. Plant and Soil 435(1):367-384. https://doi.org/10.1007/s11104-01803901-1

Vashisth A, Nagarajan S (2010). Effect on germination and early growth characteristics in sunflower (Helianthus annuus) seeds exposed to static magnetic field. Journal of Plant Physiology 167(2):149-156. https://doi.org/10.1016/j.jplph.2009.08.011

Wang M, Ding F, Zhang S (2020). Mutation of SISBPASE aggravates chilling-induced oxidative stress by impairing glutathione biosynthesis and suppressing ascorbate-glutathione recycling in tomato plants. Frontiers in Plant Science 11:2135. https://doi.org/10.3389/fpls.2020.565701

Yadav AN, Verma P, Sachan SG, Kaushik R, Saxena AK (2018). Psychrotrophic microbiomes: molecular diversity and beneficial role in plant growth promotion and soil health. Microorganisms for green revolution. Springer, pp 197-240. https://doi.org/10.1007/978-981-10-7146-1-11

Yasmin H, Naeem S, Bakhtawar M, Jabeen Z, Nosheen A, Naz R, Keyani R, Mumtaz S, Hassan MN (2020). Halotolerant rhizobacteria Pseudomonas pseudoalcaligenes and Bacillus subtilis mediate systemic tolerance in hydroponically grown soybean (Glycine max L.) against salinity stress. PLoS One 15(4):e0231348. https://doi.org/10.1371/journal.pone.0231348 
Zhang F, Xu X, Huo Y, Xiao Y (2019). Trichoderma-inoculation and mowing synergistically altered soil available nutrients, rhizosphere chemical compounds and soil microbial community, potentially driving alfalfa growth. Frontiers in Microbiology 9. https://doi.org/10.3389/fmicb.2018.03241

Zhang Y, Li Y, Hassan MJ, Li Z, Peng Y (2020). Indole-3-acetic acid improves drought tolerance of white clover via activating auxin, abscisic acid and jasmonic acid related genes and inhibiting senescence genes. BMC Plant Biology 20(1):1-12. https://doi.org/10.1186/s12870-020-02354-y
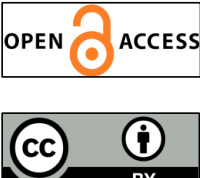

The journal offers free, immediate, and unrestricted access to peer-reviewed research and scholarly work. Users are allowed to read, download, copy, distribute, print, search, or link to the full texts of the articles, or use them for any other lawful purpose, without asking prior permission from the publisher or the author.

License - Articles published in Notulae Botanicae Horti Agrobotanici Cluj-Napoca are Open-Access, distributed under the terms and conditions of the Creative Commons Attribution (CC BY 4.0) License.

(c) Articles by the authors; UASVM, Cluj-Napoca, Romania. The journal allows the author(s) to hold the copyright/to retain publishing rights without restriction. 